\title{
Nitrous oxide and methane in a changing Arctic Ocean
}

\author{
Andrew P. Rees $(\mathbb{D}$, Hermann W. Bange, Damian L. Arévalo-Martínez, \\ Yuri Artioli, Dawn M. Ashby, Ian Brown, Hanna I. Campen, \\ Darren R. Clark, Vassilis Kitidis, Gennadi Lessin, Glen A. Tarran, \\ Carol Turley
}

Received: 4 May 2021/Revised: 13 August 2021/Accepted: 15 September 2021/Published online: 10 October 2021

\begin{abstract}
Human activities are changing the Arctic environment at an unprecedented rate resulting in rapid warming, freshening, sea ice retreat and ocean acidification of the Arctic Ocean. Trace gases such as nitrous oxide $\left(\mathrm{N}_{2} \mathrm{O}\right)$ and methane $\left(\mathrm{CH}_{4}\right)$ play important roles in both the atmospheric reactivity and radiative budget of the Arctic and thus have a high potential to influence the region's climate. However, little is known about how these rapid physical and chemical changes will impact the emissions of major climate-relevant trace gases from the Arctic Ocean. The combined consequences of these stressors present a complex combination of environmental changes which might impact on trace gas production and their subsequent release to the Arctic atmosphere. Here we present our current understanding of nitrous oxide and methane cycling in the Arctic Ocean and its relevance for regional and global atmosphere and climate and offer our thoughts on how this might change over coming decades.
\end{abstract}

Keywords Arctic Ocean - Environmental change · Ice retreat $\cdot$ Methane $\cdot$ Nitrous oxide $\cdot$ Ocean acidification . Warming

\section{BACKGROUND}

The Earth's polar regions are rapidly changing as a direct result of our altered climate. The recent IPCC special report on the oceans and the cryosphere (IPCC 2019) found that "The polar regions are losing ice, and their oceans are changing rapidly. The consequences of this polar transition

Supplementary Information The online version contains supplementary material available at https://doi.org/10.1007/s13280021-01633-8. extend to the whole planet, and are affecting people in multiple ways". The changes that are being experienced are having and will continue to have an increasing effect on the biogeochemical processes which are fundamental to the functioning of marine ecosystems (Rees 2012). The Arctic Ocean (AO) is experiencing this climate driven modification of its environment faster than anywhere else on the globe and there is high confidence that this region will likely become practically sea ice-free during the seasonal sea ice minimum for the first time before 2050, the practically ice-free state is projected to occur more often and with higher greenhouse gas concentrations (Fox-Kemper et al. 2021). To add to the complexity of this change, the loss of ice will be accompanied by the combined effects of increasing temperatures (Huang et al. 2017) and ocean acidification (AMAP 2018). Each of these artefacts of change have the potential to disrupt the biological processes which control the production and consumption of the atmospherically important trace gases nitrous oxide $\left(\mathrm{N}_{2} \mathrm{O}\right)$ and methane $\left(\mathrm{CH}_{4}\right)$, whilst some of these effects may also modify the physical exchange between ocean layers or between the ocean and atmosphere.

As both of these gases are strongly radiatively active and their release from the Arctic Ocean will be impacted by ongoing and projected environmental changes, there is a need to further our understanding of how this might alter regional and global climate and ultimately impact society. The project "Pathways and emissions of climate-relevant trace gases in a changing Arctic Ocean (PETRA)" was designed to address these issues. In this paper we set observational and experimental evidence from a PETRA research cruise to the Fram Strait in July 2018 on board RV Polarstern (PS114) within the context of previous measurements of $\mathrm{N}_{2} \mathrm{O}$ and $\mathrm{CH}_{4}$ made by ourselves and others over the pan-Arctic region to assess our current 
understanding and to consider likely scenarios of change of $\mathrm{N}_{2} \mathrm{O}$ and $\mathrm{CH}_{4}$ in a future Arctic Ocean.

\section{NITROUS OXIDE $\left(\mathrm{N}_{2} \mathrm{O}\right)$}

$\mathrm{N}_{2} \mathrm{O}$ is a long-lived atmospheric trace gas whose atmospheric mixing ratio is increasing at a mean rate of $0.85 \pm 0.03 \mathrm{ppb} \mathrm{yr}^{-1}$ (Canadell et al. 2021). It is rated as the third most important greenhouse gas (GHG) in the troposphere (Butler and Montzka 2018; Canadell et al. 2021) with a global warming potential on a 100-year timescale of approximately 300 times that of $\mathrm{CO}_{2}$ ( $\mathrm{Ra}-$ maswamy et al. 2001; Etminan et al. 2016) and is involved in ozone $\left(\mathrm{O}_{3}\right)$ depletion in the stratosphere (Ravishankara et al. 2009). Though the $\mathrm{N}_{2} \mathrm{O}$ concentration in most of the surface of the ocean is in close equilibrium with the atmosphere (Nevison et al. 1995), global emissions from the open ocean and coastal waters contribute 35-39\% of the total natural sources of $\mathrm{N}_{2} \mathrm{O}$ (Tian et al. 2020) and there is a fine balance between the ocean acting as net producer or consumer of $\mathrm{N}_{2} \mathrm{O}$. Environmental effects associated with a changing climate, which include rising temperatures, oxygen depletion and ocean acidification are quite likely to impact the level of this equilibrium (Bange et al. 2019).

Nitrous oxide is biologically produced through three processes: Denitrification is the anaerobic reduction of $\mathrm{NO}_{3}{ }^{-}$to $\mathrm{N}_{2}$ which has $\mathrm{N}_{2} \mathrm{O}$ as an intermediate; nitrification involves the two stage aerobic oxidation of $\mathrm{NH}_{4}{ }^{+}$through $\mathrm{NO}_{2}{ }^{-}$to $\mathrm{NO}_{3}{ }^{-}$, where the release of $\mathrm{N}_{2} \mathrm{O}$ as a by-product is dependent on the ambient $\mathrm{O}_{2}$ concentration (Goreau et al. 1980; Löscher et al. 2012). In the third route, nitrifierdenitrification, $\mathrm{N}_{2} \mathrm{O}$ can be formed during the reduction of $\mathrm{NO}_{2}{ }^{-}$via nitric oxide to $\mathrm{N}_{2} \mathrm{O}$ by ammonia oxidizing bacteria. The pathway by which $\mathrm{N}_{2} \mathrm{O}$ is produced by ammonia oxidizing archaea is not yet fully understood $(\mathrm{Wu}$ et al. 2020).

\section{METHANE $\left(\mathrm{CH}_{4}\right)$}

$\mathrm{CH}_{4}$ is the most abundant organic trace gas in the environment, it plays an important role in the Earth's climate and as a result of anthropogenic activities its atmospheric mixing ratio has more than doubled since the preindustrial era (Etminan et al. 2016). $\mathrm{CH}_{4}$ acts to limit the tropospheric oxidative capacity and is the second most important greenhouse gas, with a global warming potential that exceeds $\mathrm{CO}_{2}$ by up to 32 times over a 100-year timescale (Etminan et al. 2016; Canadell et al. 2021), contributing approximately $20 \%$ of the radiative climate forcing for all GHGs. The world's oceans are a natural source of $\mathrm{CH}_{4}$ but play only a minor role in its global atmospheric budget, the open ocean and coastal waters account for 7 to $12 \%$ of the total natural sources and approximately $4 \%$ of global emissions (Saunois et al. 2020). It is thought that the open ocean contributes only a minor proportion of atmospheric $\mathrm{CH}_{4}$ with coastal environments including estuaries thought to account for approximately $75 \%$ of the total marine source (Weber et al. 2019).

The origin of $\mathrm{CH}_{4}$ in marine waters is from a diverse range of sources which may be geological, including from hydrothermal vents, cold seeps, and $\mathrm{CH}_{4}$ clathrates, or microbial in origin. The source of $\mathrm{CH}_{4}$ in ocean waters continues to prove enigmatic. Traditional understanding suggests that microbial methanogenesis is an anaerobic process, which in oceanic waters is thought to occur either in oxygen deplete waters or in anoxic micro-environments that are associated with zooplankton guts and particulate material (Brooks et al. 1981; Bianchi et al. 1992; Marty et al. 1997). However, the enhanced $\mathrm{CH}_{4}$ surface saturations found far away from shelf areas are difficult to explain because conventional $\mathrm{CH}_{4}$ production via archaeal methanogenesis should not occur in the well-oxygenated surface waters. This "ocean methane paradox" has been explained in tropical and sub-tropical oligotrophic conditions by the decomposition of methylphosphonate in phosphorus starved conditions (Karl et al. 2008) whereas in Arctic waters an alternative in situ $\mathrm{CH}_{4}$ production has been proposed following the microbial cleavage of dimethylsulphoniopropionate (DMSP) (Damm et al. 2008, 2010, 2015). Indeed DMSP is often found in very high concentrations in the AO during sea ice algal blooms and sea ice brines, and is projected to increase following ongoing changes to the Arctic environment (Campen et al. 2021).

\section{CURRENT UNDERSTANDING OF $\mathrm{N}_{2} \mathrm{O}$ AND $\mathrm{CH}_{4}$ IN ARCTIC WATERS}

Concentrations of dissolved $\mathrm{N}_{2} \mathrm{O}$ in the surface waters of Arctic shelf areas and central deep basins which exchange with the atmosphere are remarkably variable and can range from pronounced undersaturation to high supersaturation (Table 1). In general, ice-free surface waters appear to be undersaturated with $\mathrm{N}_{2} \mathrm{O}$ whereas ice-covered surface waters are supersaturated with $\mathrm{N}_{2} \mathrm{O}$ (Kitidis et al. 2010; Randall et al. 2012; Fenwick et al. 2017). For the North American $\mathrm{AO}$ it was suggested that high levels of $\mathrm{N}_{2} \mathrm{O}$ were largely associated with production in the shelf sediments of Chukchi and Bering Sea's with subsequent advection eastwards (Fenwick et al. 2017). Supersaturations of $\mathrm{N}_{2} \mathrm{O}$ were also associated with the continental shelf for this region during the 7th Chinese National Arctic Research Expedition (Zhan et al. 2017, 2021) who also 
Table 1 Exemplar $\mathrm{N}_{2} \mathrm{O}$ and $\mathrm{CH}_{4}$ publications from Arctic waters to indicate variability in regional source-sink characteristics for the two gases in the upper water column likely to exchange with the overlying atmosphere

\begin{tabular}{|c|c|c|c|}
\hline Region & $\begin{array}{l}\text { Saturation Range (\%) } \\
\text { (Concentration Range (nM)) }\end{array}$ & $\begin{array}{l}\text { Potential for } \\
\text { Source - Sink }\end{array}$ & Reference \\
\hline \multicolumn{4}{|l|}{$\mathrm{N}_{2} \mathrm{O}$} \\
\hline $\begin{array}{l}\text { Labrador Sea - South Baffin Bay } \\
\text { Baffin Bay - Marginal ice } \\
\text { Baffin Bay North \& Lancaster Sound } \\
\text { Canadian Archipelago } \\
\text { Amundsen Gulf - Beaufort Sea }\end{array}$ & $\begin{array}{l}109 \pm 9(15.4 \pm 1.6) \\
117 \pm 24(19.8 \pm 3.1) \\
116 \pm 12(17.6 \pm 1.6) \\
117 \pm 15(21.0 \pm 2.8) \\
115 \pm 7(17.0 \pm 1.0)\end{array}$ & $\begin{array}{l}\text { Equilibrium-Source } \\
\text { Source } \\
\text { Source } \\
\text { Source } \\
\text { Source }\end{array}$ & $\begin{array}{l}\text { (Kitidis et al. 2010) } \\
<100 \% \text { attributed to melt-water. } \\
>100 \% \text { found under multi-year } \\
\text { sea-ice }\end{array}$ \\
\hline $\begin{array}{ll}\text { Amundsen Gulf: } & \begin{array}{l}\text { Sea Ice } \\
\text { Water under ice }\end{array}\end{array}$ & $\begin{array}{l}\sim 15-39(<3-7.9) \\
60-111(11-18.8)\end{array}$ & $\begin{array}{l}\text { Sink } \\
\text { Sink }\end{array}$ & (Randall et al. 2012) \\
\hline $\begin{array}{l}\text { Chukchi Sea: } \quad \text { Inner shelf } \\
\qquad \begin{array}{l}\text { Outer shelf } \\
\text { Abyssal plain }\end{array}\end{array}$ & $\begin{array}{l}106-157(12.1-25.1) \\
95-100(12.7-16.4) \\
92-94(16.3-16.9)\end{array}$ & $\begin{array}{l}\text { Source } \\
\text { Equilibrium-Sink } \\
\text { Sink }\end{array}$ & $\begin{array}{l}\text { (Hirota et al. 2009, Zhan et al. } \\
\text { 2017, Zhan et al. 2021) } \\
\text { (Zhang et al. 2015) } \\
\text { (Zhang et al. 2015, Zhan et al. } \\
\text { 2021) }\end{array}$ \\
\hline Bering Sea & $102-137(9.6-21.8)$ & Source & $\begin{array}{l}\text { (Hirota et al. 2009, Zhan et al. } \\
\text { 2017, Zhan et al. 2021) }\end{array}$ \\
\hline $\begin{array}{l}\text { North American Arctic: } \\
\text { Surface waters - ice free } \\
\text { Surface waters - ice covered } \\
\text { Alaskan Coastal Water } \\
\text { Pacific Summer Water } \\
\text { Pacific Winter Water }\end{array}$ & $\begin{array}{l}77-145(10.9-24.6) \\
<100 \% \\
<110 \%(<17.8) \\
\sim 100 \% \\
<120 \%(\text { mean } 17.0) \\
<145 \%(\text { mean } 24.6)\end{array}$ & $\begin{array}{l}\text { Sink } \\
\text { Source } \\
\text { Equilibrium } \\
\text { Source } \\
\text { Source }\end{array}$ & (Fenwick et al. 2017) \\
\hline $\begin{array}{lr}\text { Eurasian basin: } \quad \begin{array}{r}\text { Nansen Basin } \\
\text { Amundsen Basin }\end{array} & \end{array}$ & $\begin{array}{l}42-<100 \\
<100-111\end{array}$ & $\begin{array}{l}\text { Sink } \\
\text { Source }\end{array}$ & (Verdugo et al. 2016) \\
\hline Nordic Seas & $\begin{array}{l}82-100(9.7-15.1) \\
95-107(11.6-18.2)\end{array}$ & $\begin{array}{l}\text { Sink } \\
\text { Sink to Source }\end{array}$ & $\begin{array}{l}\text { (Zhan et al. 2016, Rees et al. } \\
\text { 2021) } \\
\text { This study, Fig. 1a }\end{array}$ \\
\hline \multicolumn{4}{|l|}{$\mathrm{CH}_{4}$} \\
\hline $\begin{array}{l}\text { Labrador Sea - South Baffin Bay } \\
\text { Baffin Bay - Marginal ice } \\
\text { Baffin Bay North \& Lancaster Sound } \\
\text { Canadian Archipelago } \\
\text { Amundsen Gulf - Beaufort Sea }\end{array}$ & $\begin{array}{l}139 \pm 45(4.2 \pm 1.3) \\
170 \pm 51(5.9 \pm 1.6) \\
164 \pm 65(5.3 \pm 2.1) \\
226 \pm 94(8.2 \pm 3.5) \\
151 \pm 76(4.9 \pm 2.8)\end{array}$ & $\begin{array}{l}\text { Equilibrium-Source } \\
\text { Source } \\
\text { Equilibrium-Source } \\
\text { Source } \\
\text { Equilibrium-Source }\end{array}$ & (Kitidis et al. 2010) \\
\hline $\begin{array}{l}\text { North American Arctic: } \\
\text { Surface Bering, Chukchi, Canada Basin. }\end{array}$ & $\begin{array}{l}95-220(3.0-7.3) \\
97-517(3.5-20.9)\end{array}$ & Equilibrium-Source & $\begin{array}{l}\text { (Fenwick et al. 2017) } \\
\text { (Li et al. 2017) }\end{array}$ \\
\hline Surface Canadian Arctic Archipelago & $<420 \%$ (mean 15.0$)$ & Source & (Fenwick et al. 2017) \\
\hline Central Arctic: & $\begin{array}{l}(1.5-3.5) \\
(\sim 4-\sim 6)\end{array}$ & $\begin{array}{l}\sim \text { Equilibrium } \\
\text { Source }\end{array}$ & (Damm et al. 2010) \\
\hline $\begin{array}{l}\text { Atlantic Water } \\
\text { Pacific Water }\end{array}$ & $\begin{array}{l}(3-3.5) \\
(4-9)\end{array}$ & $\begin{array}{l}\sim \text { Equilibrium } \\
\text { Source }\end{array}$ & (Damm et al. 2015) \\
\hline Nordic Seas & $93-132$ & Sink to Source & This study, Fig. 1b \\
\hline
\end{tabular}

noted that offshore waters tended to be in equilibrium with the atmosphere. The Nordic Seas associated with the Greenland Basin and Fram Strait have been reported to be undersaturated in $\mathrm{N}_{2} \mathrm{O}$ (Rees et al. 2021) and act as a permanent sink to atmospheric $\mathrm{N}_{2} \mathrm{O}$ (Zhan et al. 2016).
During research cruise PS114 onboard the German vessel RV Polarstern to the Fram Strait in July 2018 we measured concentrations and saturations of dissolved $\mathrm{N}_{2} \mathrm{O}$ and $\mathrm{CH}_{4}$ (Fig. 1) using an autonomous equilibrator headspace setup coupled to a trace gas cavity ringdown spectroscopy 
analyzer (Picarro Inc., USA; see Supplementary Material for methodology). The saturation of a dissolved gas indicates the relative amount of gas held relative to the value expected $(100 \%)$ when the water body is in equilibrium with the overlying atmosphere. Supersaturated waters $(>100 \%)$ indicate a local source of the particular gas whereas a value of undersaturation $(<100 \%)$ indicates the potential for a sink to the atmosphere. In Fig. 1a, saturations of $\mathrm{N}_{2} \mathrm{O}$ can be seen to vary from a minimum of $95 \%$ in the southeast of the region close to Svalbard associated with the poleward West Spitsbergen Current and Atlantic influenced open-water. In the west of the region, higher levels of $\mathrm{N}_{2} \mathrm{O}$, up to $107 \%$, were found in shallower, icecovered water close to Greenland and associated with the southerly flowing East Greenland Current. The heterogeneous distribution of $\mathrm{N}_{2} \mathrm{O}$ does not relate directly to surface ice-cover and maybe associated with the origin of source waters, though the higher concentrations to the west are likely the product of shelf sediment production and limited exchange with the atmosphere.

At present, $\mathrm{N}_{2} \mathrm{O}$ emission estimates indicate that the overall net release of $\mathrm{N}_{2} \mathrm{O}$ from the $\mathrm{AO}$ to the atmosphere is comparably low (Fenwick et al. 2017). Microbial nitrification and/or denitrification in shelf sediments as well as water column nitrification have been proposed as the main $\mathrm{N}_{2} \mathrm{O}$ production pathways in the AO shelf areas and central deep basins (Kitidis et al. 2010; Verdugo et al. 2016; Fenwick et al. 2017), whereas loss processes include biological consumption (Verdugo et al. 2016; Rees et al. 2021) and physical advection (Zhan et al. 2016). Indications for the future release of $\mathrm{N}_{2} \mathrm{O}$ are conflicting. It was suggested that the ongoing decline of the Arctic sea ice cover may enhance future $\mathrm{N}_{2} \mathrm{O}$ emissions to the atmosphere (Kitidis et al. 2010) whilst in contrast, ongoing ocean acidification (AMAP 2018) has been shown to decrease $\mathrm{N}_{2} \mathrm{O}$ production in AO waters (Rees et al. 2016). The dominating $\mathrm{N}_{2} \mathrm{O}$ pathways and their dependence from changing environmental parameters/stressors (temperature, ocean acidification) and modifications of exchange across boundary layers need to be verified. Improved emission estimates of $\mathrm{N}_{2} \mathrm{O}$ to the atmosphere, as well as mechanistic understanding on how they might be affected by the above-mentioned perturbations is crucial since currently the uncertainties on the marine source of this gas to the atmosphere in the region are extremely high at approximately $100 \%$ (Yang et al. 2020).

Very high $\mathrm{CH}_{4}$ surface saturations have been observed in the shelf areas and the central deep basins of the AO (Table 1). Vast areas of the AO seafloor, particularly those associated with Siberian, Chukchi, and Beaufort Seas, is rich in permafrost (a potential substrate for methanogenesis) and $\mathrm{CH}_{4}$ hydrates (Chen et al. 2021). At present, the $\mathrm{AO}$ is a potentially important source of atmospheric $\mathrm{CH}_{4}$
(Kort et al. 2012) with sedimentary production via methanogenesis, dissociating gas hydrates and diffusion from geological dissolution providing the dominant source in shelf sea areas. Release of bubbles from sedimentary origin during the melting season represents a considerable, yet spatially constrained, source to the atmosphere (Thornton et al. 2020), though there is evidence to indicate that $\mathrm{CH}_{4}$ released at the sea bed may not reach the atmosphere, e.g. (Myhre et al. 2016). In Fig. 1b, $\mathrm{CH}_{4}$ saturations in the Fram Strait region during July 2018 can be seen to be highly variable. As with the distribution of $\mathrm{N}_{2} \mathrm{O}$ (Fig. 1a) and patterns of heterogeneity previously reported, minimum saturations $(\sim 93 \%)$ of $\mathrm{CH}_{4}$ were associated with Atlantic influenced ice-free waters and the highest observed (132\%) were found in ice-covered areas close to the Greenland coast suggesting a strong source of $\mathrm{CH}_{4}$ to the air for this region.

Future $\mathrm{CH}_{4}$ emissions from open ocean regions of the $\mathrm{AO}$ will largely be determined by aerobic $\mathrm{CH}_{4}$ oxidation in the water column and 'non-conventional' microbial $\mathrm{CH}_{4}$ production via DMSP (Damm et al. 2010, 2015). The increased supply of organic matter from rivers and permafrost thaw may further enhance microbial methanogenesis. The effect of future environmental stressors such as warming and $\mathrm{pH}$ on aerobic $\mathrm{CH}_{4}$ oxidation is largely unknown (James et al. 2016).

\section{EVIDENCE FOR POTENTIAL CHANGE}

\section{Impact of warming}

Warming conditions are likely to impart direct and in-direct effects on the processes controlling production and consumption of both gases. Whereas the solubility of gases is governed by well constrained laws of physics under the control of temperature and salinity, so that warmer waters hold less gas than cold ones, the composition of microbial communities and their ecological function of changing systems is much less predictable. Warming would further enhance microbial methanogenesis with a $2^{\circ}$ increase in temperature resulting in a $25-200 \%$ increase in methanogenesis (Bange et al. 1998). Finally, sea ice loss as a result of warming may result in shorter residence time for $\mathrm{CH}_{4}$ and $\mathrm{N}_{2} \mathrm{O}$ in the water and thereby evasion to the atmosphere rather than in-water microbial processing (sea ice is currently considered as a semi-permeable barrier to air-sea exchange) (Kitidis et al. 2010). Increasing seawater temperatures lower the solubility of $\mathrm{CH}_{4}$ in seawater and allow a shallowing of the $\mathrm{CH}_{4}$ hydrate stability zone. Therefore, a small increase in seawater temperature could potentially lead to hydrate dissolution and the subsequent release of $\mathrm{CH}_{4}$ from the AO to the atmosphere (Kitidis 2009). 
(a)

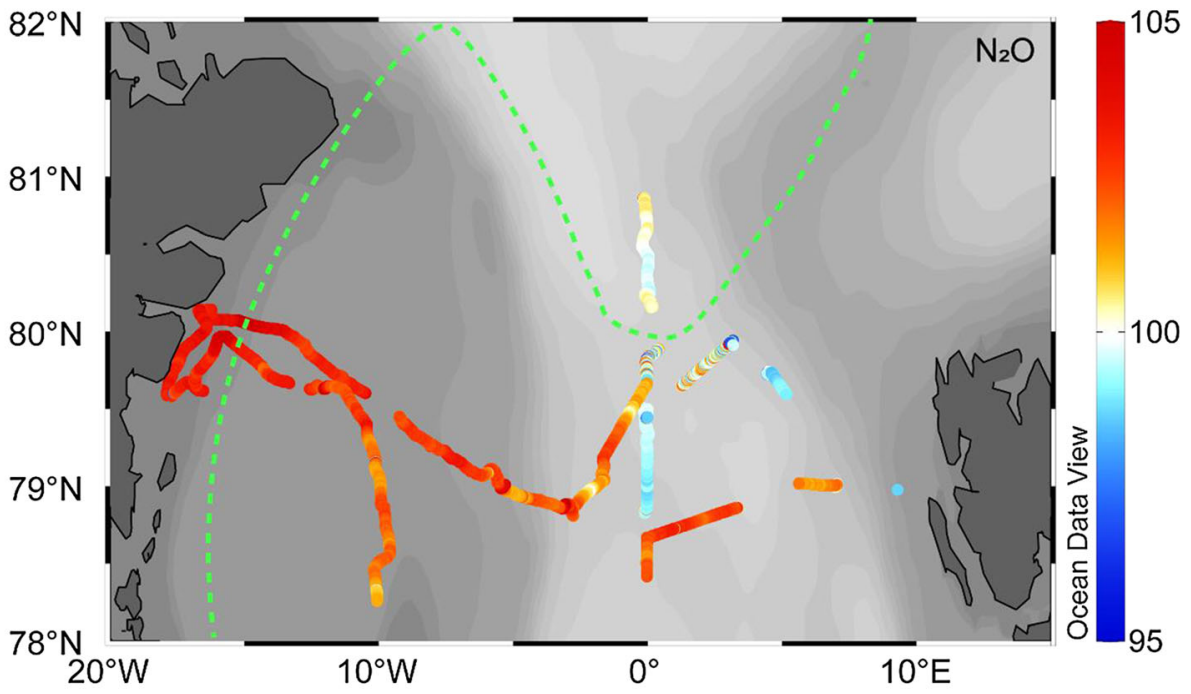

(b)

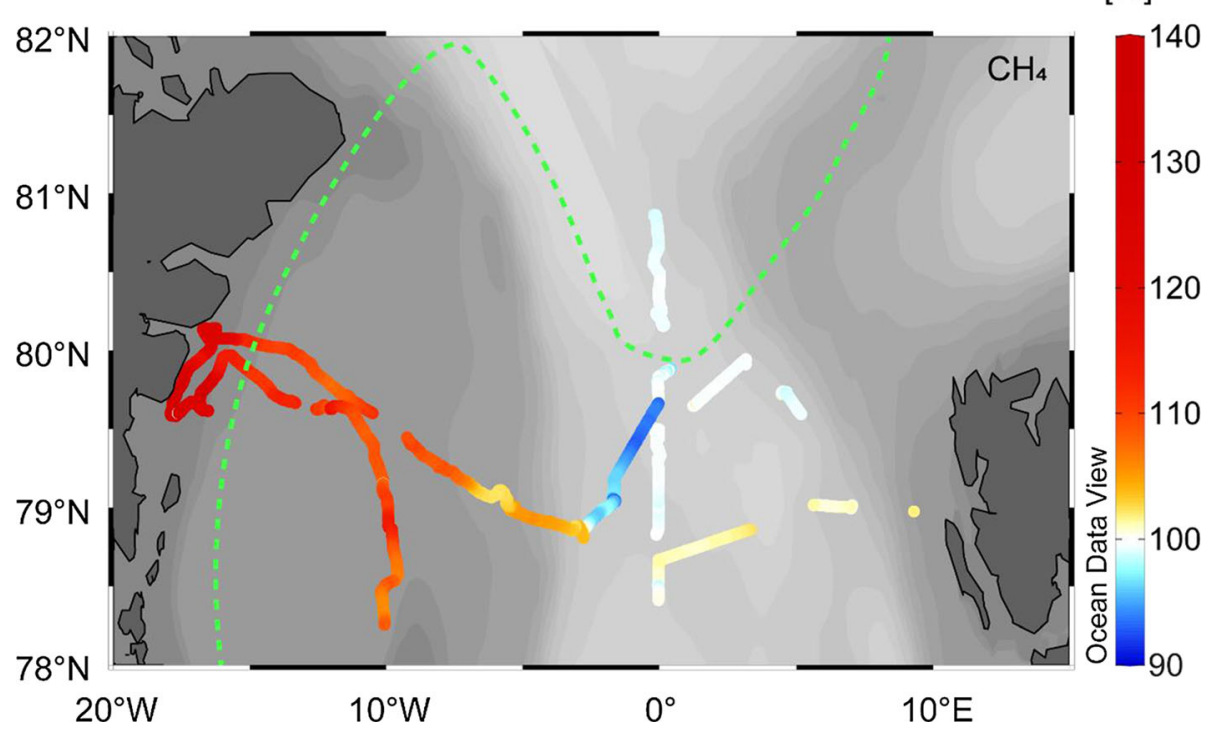

Fig. 1 Distribution of (a) $\mathrm{N}_{2} \mathrm{O}$ and (b) $\mathrm{CH}_{4}$ saturation during research cruise PS114 onboard the RV Polarstern during July 2018. The green dotted line in each image represents the southern extent of sea ice at $90 \%$ cover (see Supplementary Material for method description)

There is some confidence that phytoplankton primary productivity is likely to increase as ice-cover retreats (Lannuzel et al. 2020) which will increase the sediment load of organic material that is potentially used in remineralisation processes in the generation of both $\mathrm{N}_{2} \mathrm{O}$ and $\mathrm{CH}_{4}$. Increases in primary production can be attributed to the interplay between two factors: first, the increased spatial and temporal extent of open waters, and second, the enhanced nutrient input brought about by mixing, upwelling and lateral advection, all of which is fostered by increased inflow from subpolar seas (the so-called Atlantification of Arctic waters) and more frequent storm events (Polyakov et al. 2017).
As ocean temperatures rise, $\mathrm{CH}_{4}$ hydrates may become unstable releasing vast quantities of $\mathrm{CH}_{4}$ to the atmosphere which in turn may lead to further temperature increase and hydrate de-stabilisation according to the "clathrate gun" hypothesis (Kennett et al. 2003).

Although $\mathrm{CH}_{4}$ solubility will decrease with increasing temperature, methanotrophy will also increase (YvonDurocher et al. 2014). Methanotrophy is the dominant oceanic $\mathrm{CH}_{4}$ sink and is a first order process with respect to $\mathrm{CH}_{4}$ concentration and inversely related to its turnover time. This suggests that an enhanced sedimentary release, potentially caused by warming triggered gas hydrate dissociation may result in shorter turnover times of dissolved 
$\mathrm{CH}_{4}$ in the water column (James et al. 2016). However, direct ebullition from dissociating gas hydrates or thawing permafrost may result in substantial emission of $\mathrm{CH}_{4}$ to the atmosphere as bubbles rise faster than they are consumed by microbes (Shakhova et al. 2010). Decreased sea ice would also reduce the extent of areas where bubbles released from the sediments are trapped. The transfer of these bubbles across the sea surface during the melting season might represent a spatially variable, yet considerable source of $\mathrm{CH}_{4}$ to the atmosphere (Zhou et al. 2014).

\section{IMPACT OF OCEAN ACIDIFICATION}

In the open oceans nitrification is the dominant mechanism for the production of $\mathrm{N}_{2} \mathrm{O}$. A number of studies have shown that nitrification rate is inhibited by decreasing $\mathrm{pH}$ (Beman et al. 2010; Kitidis et al. 2011) but the impact on $\mathrm{N}_{2} \mathrm{O}$ appears equivocal. During experiments performed in Arctic and Antarctic waters (Rees et al. 2016) showed that whilst the microbial community of ammonia oxidising archaea (the dominant nitrifying organisms) seemed unaffected by changing $\mathrm{pH}$, the production of $\mathrm{N}_{2} \mathrm{O}$ decreased at all stations by between 2.4 and $44 \%$ when $\mathrm{pH}$ was reduced at between values of 0.06 and $0.4 \mathrm{pH}$ units. The reduction in $\mathrm{N}_{2} \mathrm{O}$ yield from nitrification was directly related to a decrease of between 28 and $67 \%$ in available $\mathrm{NH}_{3}$ as a result of the $\mathrm{pH}$ driven shift in the $\mathrm{NH}_{3}: \mathrm{NH}_{4}{ }^{+}$equilibrium. In the subarctic western North Pacific (Breider et al. 2019) found that decreasing the $\mathrm{pH}$ during experimental manipulations acted to significantly increase $\mathrm{N}_{2} \mathrm{O}$ production, whilst rates of nitrification either remained stable or decreased, indicating a de-coupling of the two processes. The differences between the findings of Rees et al (2016) and Breider et al (2019) maybe attributable to regionally associated differences in $\mathrm{N}_{2} \mathrm{O}$ production pathways, or to the relative sensitivities of microbial communities found in the two regions.

During the current project we performed four experiments during PS114 in the Fram Strait region similar to those described in Rees et al (2016). These were conducted to examine the impact of ocean acidification in isolation and in combination with warming of $2{ }^{\circ} \mathrm{C}$ (see Supplementary Material for methodology). Initial findings can be seen in Fig. 2. It would appear that there is a decrease in both $\mathrm{N}_{2} \mathrm{O}$ concentration and in nitrification rate with changes of $\mathrm{pH}$ which were made to match future conditions indicated by representative concentration pathway (RCP) of 6.0 and 8.5. Whilst there is some inherent variability in the responses, it would appear that there is no obvious response of $\mathrm{N}_{2} \mathrm{O}$ production or nitrification rate to warming of $2{ }^{\circ} \mathrm{C}$.

To date we are unaware of experimental evidence to suggest that either methanogenesis or methanotrophy show any sensitivity to changing conditions of ocean acidification. A limited number of experiments that we have performed have all indicated that both $\mathrm{CH}_{4}$ production and consumption processes are likely to prove resilient to ocean acidification in the AO.

\section{ECOSYSTEM MODELLING}

The incorporation of up-to-date knowledge of $\mathrm{N}_{2} \mathrm{O}$ and $\mathrm{CH}_{4}$ dynamics in the marine environment into coupled physical-biogeochemical models is important to (a) expand our understanding and to test hypotheses related to the dynamics of these gases, (b) to explain spatial and temporal distribution patterns, and (c) to predict future change under the impact of multiple stressors. However there is currently insufficient understanding of the production and consumption pathways of these gases and their environmental controls which remains a limiting factor for their wider inclusion into process-based model studies, both in the AO and elsewhere.

A range of model formulations of $\mathrm{N}_{2} \mathrm{O}$ dynamics based on observational data have been developed in recent years and applied at a global scale, e.g. (Martinez-Rey et al. 2015; Ji et al. 2018) thus covering, but not focusing on, the AO region. However, implementation of regional-scale models of $\mathrm{N}_{2} \mathrm{O}$ is hindered by the scarcity of observational data and incompleteness in understanding of various pathways and their response to stressors, especially within high-gradient environments.

The issue is even more apparent for $\mathrm{CH}_{4}$, as many unknowns related to its production and consumption pathways still limit the rare modelling efforts to sensitivity studies, e.g. (Wåhlström and Meier 2014) who focused on the Laptev Sea region. Better understanding of the controls over the $\mathrm{CH}_{4}$ pathways is critical to constrain processbased models: for instance, the reported range of oceanic aerobic $\mathrm{CH}_{4}$ oxidation rates spans several orders of magnitude. In the AO the uncertainties in biological pathways are further augmented by a range of shelf sea processes related to permafrost thawing and $\mathrm{CH}_{4}$ hydrate dissolution, that all require advancements in understanding and consideration in the models.

The implementation of sophisticated process-based models which are able to project future emissions of $\mathrm{N}_{2} \mathrm{O}$ and $\mathrm{CH}_{4}$ under the influence of multiple stressors is severely hampered by sparse sampling (Weber et al. 2019) and lack of experimental evidence to advance statistically sound mechanistic understanding of the controlling processes. There is real need for an increased capacity of measurements such as those reported in this study to further develop this on both regional and global scales. 

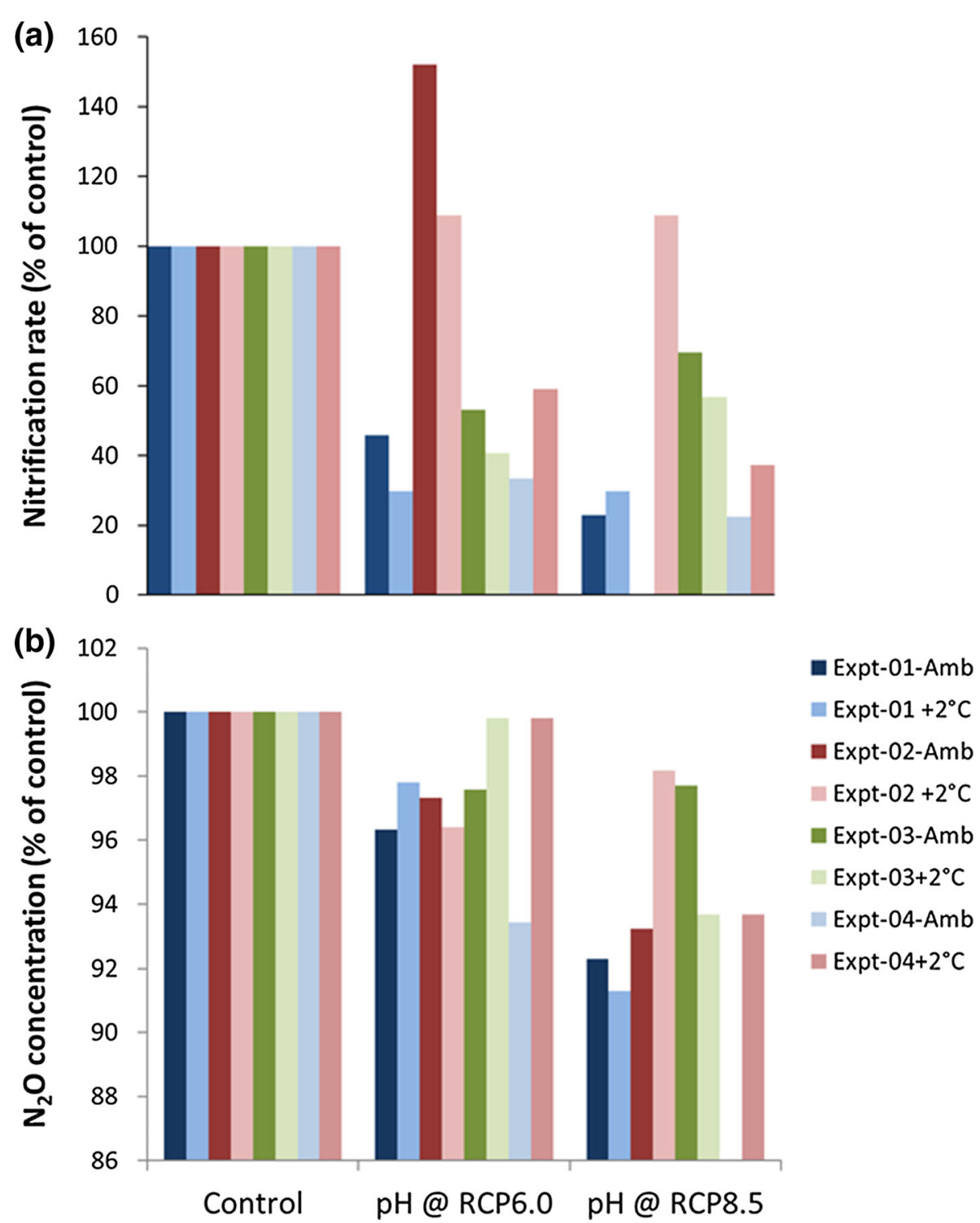

Fig. 2 The impact of decreasing ocean $\mathrm{pH}$ and increasing temperature by $2{ }^{\circ} \mathrm{C}$ on (a) the rate of nitrification and (b) $\mathrm{N}_{2} \mathrm{O}$ concentration at four positions in the Fram Straits region of the AO during research cruise PS114 in July 2018 (see Supplementary Material for method description)

\section{SOCIAL AND POLICY IMPLICATIONS}

$\mathrm{N}_{2} \mathrm{O}$ and $\mathrm{CH}_{4}$ contribute significantly to climate change. They are relevant to the United Nations Framework Convention on Climate Change (UNFCCC), the primary international, intergovernmental forum for negotiating the global response to climate change. The ultimate objective of the UNFCCC is to stabilize GHG concentrations "at a level that would prevent dangerous anthropogenic (human induced) interference with the climate system" (UNFCCC 1992). The goal of the Paris Agreement (UN 2015), a legally binding international treaty on climate change, adopted by 196 Parties at UNFCCC COP 21 in Paris in 2015, is "to limit global warming to well below 2, preferably to $1.5^{\circ} \mathrm{C}$, compared to pre-industrial levels". To achieve this long-term temperature goal, countries aim to reach global peaking of GHG emissions as soon as possible to realize a climate neutral world by mid-century.

UN Member States adopted 17 Sustainable Development Goals (SDGs), as part of the 2030 Agenda for Sustainable Development (United Nations 2015), a global partnership for sustainable improvement of human lives whilst protecting the environment, including oceans, and tackling climate change. The oceanic production of $\mathrm{N}_{2} \mathrm{O}$ and $\mathrm{CH}_{4}$ addressed in this study is relevant to climate change goal (SDG13), to "Take urgent action to combat climate change and its impacts".

The generation of impact is integral to PETRA (Fig. 3). Data generated will be managed and archived at our local 


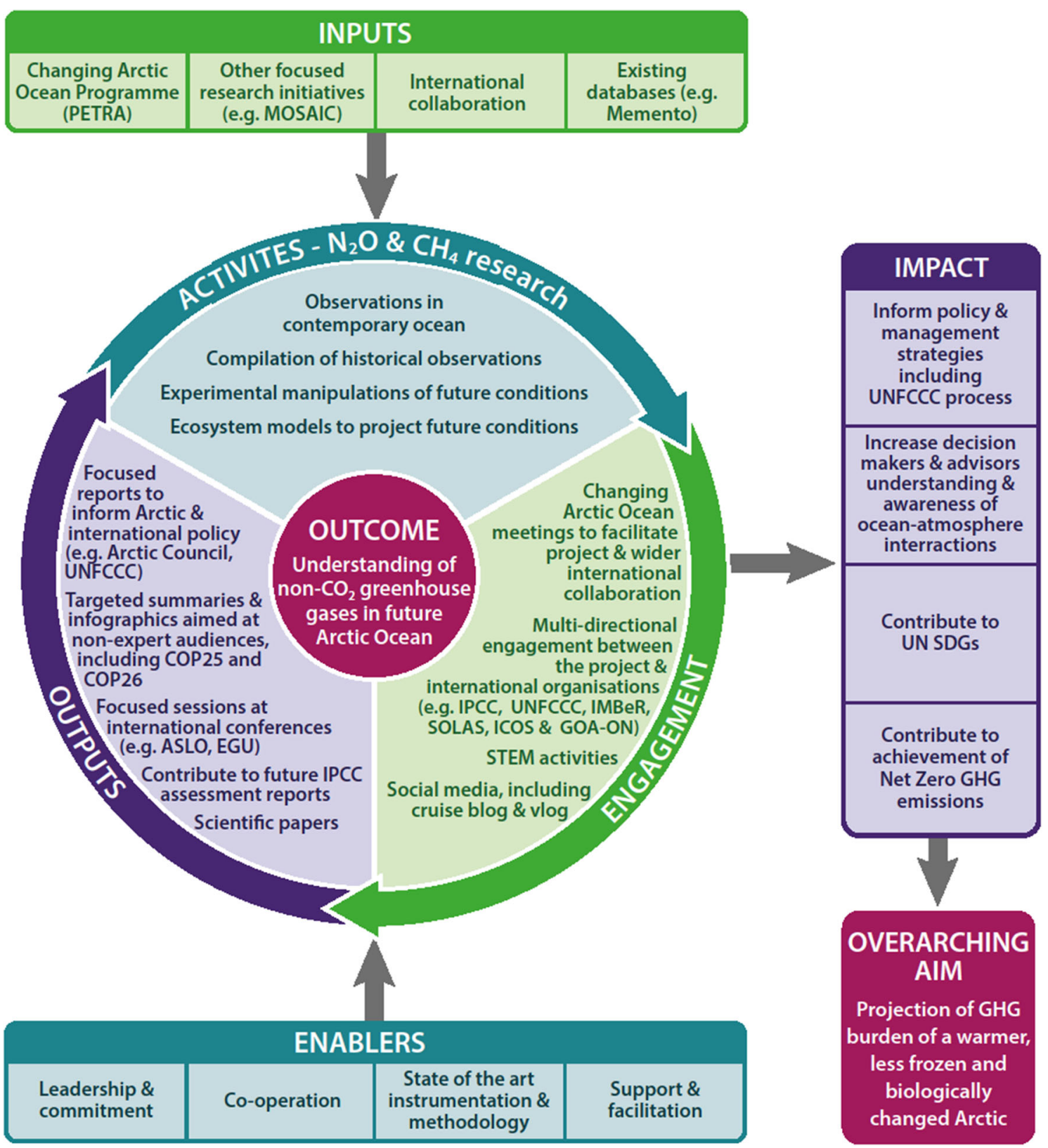

Fig. 3 Theory of Change visualisation of social and policy implications associated with the PETRA project investigations of $\mathrm{N}_{2} \mathrm{O}$ and $\mathrm{CH}_{4}$ in a changing $\mathrm{AO}$

oceanographic data centres (British Oceanographic Data Centre for UK and PANGEA for Germany) according to our data management plan. To ensure greater visibility and access, $\mathrm{CO}_{2}$ data collected during fieldwork expeditions in 2018 and 2019 have been submitted to the Surface Ocean $\mathrm{CO}_{2}$ Atlas (SOCAT) and included in the annual Global Carbon Project budget (Friedlingstein et al. 2020) whilst $\mathrm{N}_{2} \mathrm{O}$ and $\mathrm{CH}_{4}$ data will be submitted to the marine methane and nitrous oxide database (MEMENTO) (https://memento. geomar.de/). Outputs will also be made available through engagement with the GOA-ON observational network.
"The polar regions are losing ice, and their oceans are changing rapidly. The consequences of this polar transition extend to the whole planet, and are affecting people in multiple ways" (IPCC 2019). Understanding the role of the ocean in the cycling and production of $\mathrm{N}_{2} \mathrm{O}$ and $\mathrm{CH}_{4}$ and how these may change in an ocean undergoing rapid and long-term change is therefore essential to the Convention and climate negotiations. The findings of our previous work (Rees et al. 2016) and the newer observations from PETRA indicate that ocean acidification has the potential to decrease $\mathrm{N}_{2} \mathrm{O}$ emissions by up to $0.8 \mathrm{Tg} \mathrm{N} \mathrm{yr}^{-1}$ which is 
Table 2 Sources and sinks of $\mathrm{N}_{2} \mathrm{O}$ and $\mathrm{CH}_{4}$ in the AO, the expected effect of ocean warming (and associated melting) and acidification, as well as the level of uncertainties in the current state of knowledge

\begin{tabular}{lllll}
\hline Processes & Source/sink & \multicolumn{2}{l}{ Estimated overall effect ${ }^{\mathrm{a}}$} & Level of uncertainty \\
\cline { 4 - 5 } & & Warming & Ocean acidification \\
\hline $\mathrm{N}_{2} \mathrm{O}$ & & & $\downarrow$ & Medium \\
Nitrification & Source & $\uparrow$ & $?$ & Medium \\
Denitrification & Source/sink & $\uparrow$ & $\downarrow$ & High \\
Air-sea exchange & Source/sink & $\uparrow$ & $?$ & Very high \\
Within-ice cycling \& fluxes & Source/sink & $?$ & & Medium \\
$\mathrm{CH}_{4}$ & & & $?$ & Medium \\
Methanogenesis & Source & $\uparrow$ & $?$ & High \\
Methanotrophy & Sink & $\uparrow$ & $?$ & High \\
Aerobic oxidation & Sink & $\uparrow$ & $?$ & Very high \\
Air-sea exchange & Source/sink & $\uparrow$ & $?$ & $?$ \\
Within-ice cycling \& fluxes & Source/sink & $?$ & $?$ \\
\hline
\end{tabular}

${ }^{\mathrm{\uparrow}}$ increase, $\downarrow$ decrease, ? unknown

comparable to all current $\mathrm{N}_{2} \mathrm{O}$ production from fossil fuel

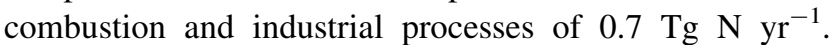
There is some potential therefore for decreases in $\mathrm{N}_{2} \mathrm{O}$ release to the atmosphere to offer a negative feedback to global warming, though it is still too early to say as other contrasting (Breider et al. 2019) and compounding effects are still to be accounted for.

\section{OUTLOOK}

Whilst estimates of the global marine source of $\mathrm{N}_{2} \mathrm{O}$ and $\mathrm{CH}_{4}$ to the atmosphere have significantly improved (Wilson et al. 2020), a mechanistic understanding of the causes for the observed variability in sink-source dynamics and sea/ice-air gradients in the AO is missing. This degree of uncertainty is highlighted in Table 2, where current understanding of the processes controlling these gases in concert with ocean acidification and warming are presented. Reduced sea ice coverage in the AO and the adjacent subpolar regions with future warming will likely expose larger ocean surfaces to direct exchange with the atmosphere, increasing the overall source of $\mathrm{N}_{2} \mathrm{O}$ and $\mathrm{CH}_{4}$ (a positive feedback on GHG-driven warming). However, the sea air transfer depends strongly on the pre-existing gradients between both reservoirs. The balance is a complex product of several processes. During the freezing period, brine rejection leads to gas enrichment and densitydriven fluxes towards the underlying water column, but also potentially supports temporary fluxes towards the atmosphere. In contrast, during melting, a dilution effect causes gas undersaturation with respect to atmospheric equilibrium together with a strong salinity driven stratification. This would result in a net ocean uptake unless a strong source (e.g. sedimentary $\mathrm{CH}_{4}$ release) or buoyancydriven flow breaks the stratification causing deep mixing and upwelling. At present it is challenging to establish which process is dominant over the annual cycle since the cycling of $\mathrm{N}_{2} \mathrm{O}$ and $\mathrm{CH}_{4}$ within the sea ice is not well understood and local production can be masked by lateral advection. Moreover, it is not clear to what extent an ocean acidification driven change of $\mathrm{N}_{2} \mathrm{O}$ production would contribute to offset the expected increase in the emissions to the atmosphere, and whether any synergistic effects may arise.

Resolving gradients across the sea-ice-air interfaces and their spatial and temporal variability requires a combination of dedicated, multidisciplinary surveys, time series observations and the use of novel methods and autonomous platforms suitable for different ice conditions, e.g. (Bange et al. 2019; Lee et al. 2019). Studies investigating dynamics of $\mathrm{N}_{2} \mathrm{O}$ and $\mathrm{CH}_{4}$ within sea ice are scarce and therefore should be addressed in future joint projects. Recent observations from the MOSAiC expedition (https://mosaic-expedition.org/) and the Synoptic Arctic Survey (https://synopticarcticsurvey.w.uib.no/) are expected to provide important contributions towards a better understanding of the cycling and emissions of $\mathrm{N}_{2} \mathrm{O}$ and $\mathrm{CH}_{4}$ in the $\mathrm{AO}$. Overall, strengthening observational capabilities in the AO will reduce the current emission uncertainties and thereby improve our projections of future GHG emission trends within the context of global coupled models.

Acknowledgements This PETRA project was supported by the Changing Arctic Ocean programme which was co-funded by UK Natural Environment Research Council and the German Federal Ministry of Education and Research with awards NE/R012830/1 and FKZ 03F0808A, respectively. 
Open Access This article is licensed under a Creative Commons Attribution 4.0 International License, which permits use, sharing, adaptation, distribution and reproduction in any medium or format, as long as you give appropriate credit to the original author(s) and the source, provide a link to the Creative Commons licence, and indicate if changes were made. The images or other third party material in this article are included in the article's Creative Commons licence, unless indicated otherwise in a credit line to the material. If material is not included in the article's Creative Commons licence and your intended use is not permitted by statutory regulation or exceeds the permitted use, you will need to obtain permission directly from the copyright holder. To view a copy of this licence, visit http://creativecommons. org/licenses/by/4.0/.

\section{REFERENCES}

AMAP. 2018. AMAP Assessment 2018: Arctic ocean acidification. Troms $\emptyset$, Norway: Arctic Monitoring and Assessment Programme.

Bange, H.W., D.L. Arevalo-Martinez, M. de la Paz, L. Farias, J. Kaiser, A. Kock, C.S. Law, A.P. Rees, et al. 2019. A Harmonized nitrous oxide (N2O) ocean observation network for the $21 \mathrm{st}$ century. Frontiers in Marine Science. https://doi.org/10.3389/ fmars.2019.00157.

Bange, H.W., S. Dahlke, R. Ramesh, L.A. Meyer-Reil, S. Rapsomanikis, and M.O. Andreae. 1998. Seasonal study of methane and nitrous oxide in the coastal waters of the Southern Baltic Sea. Estuarine, Coastal and Shelf Science 47: 807-817. https:// doi.org/10.1006/ecss.1998.0397.

Beman, J.M., C.-E. Chow, A.L. King, Y. Feng, J.A. Fuhrman, A. Andersson, N.R. Bates, B.N. Popp, et al. 2010. Global declines in oceanic nitrification rates as a consequence of ocean acidification. Proceedings of the National Academy of Sciences of the United States of America 108: 208-213. https://doi.org/10. 1073/pnas.1011053108.

Bianchi, M., D. Marty, J.L. Teyssie, and S.W. Fowler. 1992. Strictly aerobic and anaerobic bacteria associated with sinking particulate matter and zooplankton fecal pellets. Marine Ecology Progress Series 88: 55-60. https://doi.org/10.3354/meps088055.

Breider, F., C. Yoshikawa, A. Makabe, S. Toyoda, M. Wakita, Y. Matsui, S. Kawagucci, T. Fujiki, et al. 2019. Response of $\mathrm{N}_{2} \mathrm{O}$ production rate to ocean acidification in the western North Pacific. Nature Climate Change. https://doi.org/10.1038/s41558019-0605-7.

Brooks, J.M., D.F. Reid, and B.B. Bernard. 1981. Methane in the upper water column of the Northwestern Gulf of Mexico. Journal of Geophysical Research-Oceans 86: 1029-1040. https://doi.org/10.1029/JC086iC11p11029.

Butler, J.H., and S.A. Montzka. 2018. The NOAA Annual Greenhouse Gas Index (AGGI). National Oceanic and Atmospheric Administration. Retrieved 23 April 2021, from http://www.esrl. noaa.gov/gmd/aggi/aggi.html (Web material)

Campen, H.I., D.L. Arévalo-Martínez, Y. Artioli, I.J. Brown, V. Kitidis, G. Lessin, A.P. Rees, and H.W. Bange. 2021. The role of a changing Arctic Ocean and climate for the biogeochemical cycling of dimethyl sulphide (DMS) and carbon monoxide (CO). Ambio. https://doi.org/10.1007/s13280-021-01612-z.

Canadell, J.G., P.M.S. Monteiro, M.H. Costa, L. Cotrim da Cunha, P.M. Cox, A.V. Eliseev, S. Henson, M. Ishii, et al. 2021. Global carbon and other biogeochemical cycles and feedbacks. In Climate change 2021: The physical science basis. Contribution of working group $i$ to the sixth assessment report of the intergovernmental panel on climate change, ed. V. MassonDelmotte, P. Zhai, A. Pirani, S.L. Connors, C. Péan, S. Berger,
N. Caud, Y. Chen, et al. Cambridge/New York, NY: Cambridge University Press.

Chen, M.L., J.H. Kim, Y.K. Lee, D.H. Lee, Y.K. Jin, and J. Hur. 2021. Subsea permafrost as a potential major source of dissolved organic matter to the East Siberian Arctic Shelf. Science of the Total Environment. https://doi.org/10.1016/j.scitotenv.2021. 146100.

Damm, E., E. Helmke, S. Thoms, U. Schauer, E. Nothig, K. Bakker, and R.P. Kiene. 2010. Methane production in aerobic oligotrophic surface water in the central Arctic Ocean. Biogeosciences 7: 1099-1108. https://doi.org/10.5194/bg-7-1099-2010.

Damm, E., R.P. Kiene, J. Schwarz, E. Falck, and G. Dieckmann. 2008. Methane cycling in Arctic shelf water and its relationship with phytoplankton biomass and DMSP. Marine Chemistry 109: 45-59. https://doi.org/10.1016/j.marchem.2007.12.003.

Damm, E., S. Thoms, A. Beszczynska-Moller, E.M. Nothig, and G. Kattner. 2015. Methane excess production in oxygen-rich polar water and a model of cellular conditions for this paradox. Polar Science 9: 327-334. https://doi.org/10.1016/j.polar.2015.05.001.

Etminan, M., G. Myhre, E.J. Highwood, and K.P. Shine. 2016. Radiative forcing of carbon dioxide, methane, and nitrous oxide: A significant revision of the methane radiative forcing. Geophysical Research Letters 43: 12614-12623. https://doi.org/10. 1002/2016g1071930.

Fenwick, L., D. Capelle, E. Damm, S. Zimmermann, W.J. Williams, S. Vagle, and P.D. Tortell. 2017. Methane and nitrous oxide distributions across the North American Arctic Ocean during summer, 2015. Journal of Geophysical Research-Oceans 122: 390-412. https://doi.org/10.1002/2016jc012493.

Fox-Kemper, B., H.T. Hewitt, C. Xiao, G. Aðalgeirsdóttir, S.S. Drijfhout, T.L. Edwards, N.R. Golledge, M. Hemer, et al. 2021. Ocean, cryosphere and sea level change. In Climate change 2021: The physical science basis. Contribution of working group I to the sixth assessment report of the intergovernmental panel on climate change, ed. V. Masson-Delmotte, P. Zhai, A. Pirani, S.L. Connors, C. Péan, S. Berger, N. Caud, Y. Chen, et al. Cambridge/New York, NY: Cambridge University Press.

Friedlingstein, P., M. O’Sullivan, M.W. Jones, R.M. Andrew, J. Hauck, A. Olsen, G.P. Peters, W. Peters, et al. 2020. Global carbon budget 2020. Earth System Science Data 12: 3269-3340. https://doi.org/10.5194/essd-12-3269-2020.

Goreau, T.J., W.A. Kaplan, S.C. Wofsy, M.B. McElroy, F.W. Valois, and S.W. Watson. 1980. Production of $\mathrm{NO}_{2}^{-}$and $\mathrm{N}_{2} \mathrm{O}$ by nitrifying bacteria at reduced concentrations of oxygen. Applied and Environmental Microbiology 40: 526-532.

Hirota, A., A. Ijiri, D.D. Komatsu, S.B. Ohkubo, F. Nakagawa, and U. Tsunogai. 2009. Enrichment of nitrous oxide in the water columns in the area of the Bering and Chukchi Seas. Marine Chemistry 116: 47-53. https://doi.org/10.1016/j.marchem.2009.09.001.

Huang, J.B., X.D. Zhang, Q.Y. Zhang, Y.L. Lin, M.J. Hao, Y. Luo, Z.C. Zhao, Y. Yao, et al. 2017. Recently amplified arctic warming has contributed to a continual global warming trend. Nature Climate Change 7: 875-879. https://doi.org/10.1038/ s41558-017-0009-5.

IPCC. 2019. Summary for policymakers. In IPCC special report on the ocean and cryosphere in a changing climate, ed. H.-O. Pörtner, D.C. Roberts, V. Masson-Delmotte, P. Zhai, M. Tignor, E. Poloczanska, K. Mintenbeck, M. Nicolai, et al., 3-35. Geneva: Intergovernmental Panel on Climate Change.

James, R.H., P. Bousquet, I. Bussmann, M. Haeckel, R. Kipfer, I. Leifer, H. Niemann, I. Ostrovsky, et al. 2016. Effects of climate change on methane emissions from seafloor sediments in the Arctic Ocean: A review. Limnology and Oceanography 61: S283-S299. https://doi.org/10.1002/lno.10307.

Ji, Q., E. Buitenhuis, P. Suntharalingam, J.L. Sarmiento, and B.B. Ward. 2018. Global nitrous oxide production determined by 
oxygen sensitivity of nitrification and denitrification. Global Biogeochemical Cycles 32: 1790-1802. https://doi.org/10.1029/ 2018 GB005887.

Karl, D.M., L. Beversdorf, K.M. Bjorkman, M.J. Church, A. Martinez, and E.F. Delong. 2008. Aerobic production of methane in the sea. Nature Geoscience 1: 473-478. https://doi. org/10.1038/ngeo234.

Kennett, J.P., K.G. Cannariato, I.L. Hendy, and R.J. Behl. 2003. Methane hydrates in quaternary climate change: The clathrate gun hypothesis. In Methane hydrates in quaternary climate change: The clathrate gun hypothesis, ed. J.P. Kennett, K.G. Cannariato, I.L. Hendy, and R.J. Behl, 1-9. Washington, DC: American Geophysical Union.

Kitidis, V. 2009. Chapter 10. Methane biogeochemistry and carbon stores in the Arctic Ocean: Hydrates and permafrost. In Carbon capture: Sequestration and storage, ed. R.E. Hester and R.M. Harrison, 285-300. London: Royal Society of Chemistry.

Kitidis, V., B. Laverock, L.C. McNeill, A. Beesley, D. Cummings, K. Tait, M.A. Osborn, and S. Widdicombe. 2011. Impact of ocean acidification on benthic and water column ammonia oxidation. Geophysical Research Letters 38: L21603. https://doi.org/10. 1029/2011GL049095.

Kitidis, V., R.C. Upstill-Goddard, and L.G. Anderson. 2010. Methane and nitrous oxide in surface water along the North-West Passage, Arctic Ocean. Marine Chemistry 121: 80-86. https://doi.org/10. 1016/j.marchem.2010.03.006.

Kort, E.A., S.C. Wofsy, B.C. Daube, M. Diao, J.W. Elkins, R.S. Gao, E.J. Hintsa, D.F. Hurst, et al. 2012. Atmospheric observations of Arctic Ocean methane emissions up to $82^{\circ}$ north. Nature Geoscience 5: 318-321. https://doi.org/10.1038/ngeo1452.

Lannuzel, D., L. Tedesco, M. van Leeuwe, K. Campbell, H. Flores, B. Delille, L. Miller, J. Stefels, et al. 2020. The future of Arctic seaice biogeochemistry and ice-associated ecosystems. Nature Climate Change 10: 983-992. https://doi.org/10.1038/s41558020-00940-4.

Lee, C.M., S. Starkweather, H. Eicken, M.-L. Timmermans, J. Wilkinson, S. Sandven, D. Dukhovskoy, S. Gerland, et al. 2019. A framework for the development, design and implementation of a sustained Arctic Ocean observing system. Frontiers in Marine Science 6: 451. https://doi.org/10.3389/fmars.2019.00451.

Li, Y.H., L.Y. Zhan, J.X. Zhang, L.Q. Chen, J.F. Chen, and Y.P. Zhuang. 2017. A significant methane source over the Chukchi Sea shelf and its sources. Continental Shelf Research 148: 150-158. https://doi.org/10.1016/j.csr.2017.08.019.

Löscher, C.R., A. Kock, M. Koenneke, J. LaRoche, H.W. Bange, and R.A. Schmitz. 2012. Production of oceanic nitrous oxide by ammonia-oxidizing archaea. Biogeosciences 9: 2419-2429. https://doi.org/10.5194/bg-9-2419-2012.

Martinez-Rey, J., L. Bopp, M. Gehlen, A. Tagliabue, and N. Gruber. 2015. Projections of oceanic $\mathrm{N}_{2} \mathrm{O}$ emissions in the 21 st century using the IPSL Earth system model. Biogeosciences 12: 4133-4148. https://doi.org/10.5194/bg-12-4133-2015.

Marty, D., P. Nival, and W.D. Yoon. 1997. Methanoarchaea associated with sinking particles and zooplankton collected in the northeastern tropical Atlantic. Oceanologica Acta 20: $863-869$.

Myhre, C.L., B. Ferre, S.M. Platt, A. Silyakova, O. Hermansen, G. Allen, I. Pisso, N. Schmidbauer, et al. 2016. Extensive release of methane from Arctic seabed west of Svalbard during summer 2014 does not influence the atmosphere. Geophysical Research Letters 43: 4624-4631. https://doi.org/10.1002/2016gl068999.

Nevison, C.D., R.F. Weiss, and D.J. Erickson. 1995. Global oceanic emissions of nitrous-oxide. Journal of Geophysical ResearchOceans 100: 15809-15820. https://doi.org/10.1029/95JC00684.

Polyakov, I.V., A.V. Pnyushkov, M.B. Alkire, I.M. Ashik, T.M. Baumann, E.C. Carmack, I. Goszczko, J. Guthrie, et al. 2017.
Greater role for Atlantic inflows on sea-ice loss in the Eurasian Basin of the Arctic Ocean. Science. https://doi.org/10.1126/ science.aai8204.

Ramaswamy, V., O. Boucher, J. Haigh, D. Hauglustaine, J. Haywood, G. Myhre, T. Nakajima, G.Y. Shi, et al. 2001. Radiative forcing of climate change. In Climate Change 2001: The scientific basis. Contribution of working group I to the third assessment report of the intergovernmental panel on climate change, ed. J.T. Houghton, Y. Ding, D.J. Griggs, M. Noguer, P.J. Van der Linden, X. Dai, K. Maskell, and C.A. Johnson, 349-416. Cambridge: Cambridge University Press.

Randall, K., M. Scarratt, M. Levasseur, S. Michaud, H.X. Xie, and M. Gosselin. 2012. First measurements of nitrous oxide in Arctic sea ice. Journal of Geophysical Research-Oceans. https://doi.org/10. 1029/2011jc007340.

Ravishankara, A.R., J.S. Daniel, and R.W. Portmann. 2009. Nitrous oxide $\left(\mathrm{N}_{2} \mathrm{O}\right)$ : The dominant ozone-depleting substance emitted in the 21st century. Science 326: 123-125. https://doi.org/10. 1126/science. 1176985 .

Rees, A.P. 2012. Pressures on the marine environment and the changing climate of ocean biogeochemistry. Philosophical Transactions of the Royal Society a-Mathematical Physical and Engineering Sciences 370: 5613-5635. https://doi.org/10. 1098/rsta.2012.0399.

Rees, A.P., I.J. Brown, A. Jayakumar, G. Lessin, P.J. Somerfield, and B.B. Ward. 2021. Biological nitrous oxide consumption in oxygenated waters of the high latitude Atlantic Ocean. Communications Earth \& Environment 2: 36. https://doi.org/10.1038/ s43247-021-00104-y.

Rees, A.P., I.J. Brown, A. Jayakumar, and B.B. Ward. 2016. The inhibition of $\mathrm{N}_{2} \mathrm{O}$ production by ocean acidification in cold temperate and polar waters. Deep-Sea Research Part Ii-Topical Studies in Oceanography 127: 93-101. https://doi.org/10.1016/j. dsr2.2015.12.006.

Saunois, M., A.R. Stavert, B. Poulter, P. Bousquet, J.G. Canadell, R.B. Jackson, P.A. Raymond, E.J. Dlugokencky, et al. 2020. The Global Methane Budget 2000-2017. Earth System Science Data 12: 1561-1623. https://doi.org/10.5194/essd-12-1561-2020.

Shakhova, N., I. Semiletov, A. Salyuk, V. Yusupov, D. Kosmach, and O. Gustafsson. 2010. Extensive methane venting to the atmosphere from sediments of the East Siberian Arctic Shelf. Science 327: 1246-1250. https://doi.org/10.1126/science.1182221.

Thornton, B.F., J. Prytherch, K. Andersson, I.M. Brooks, D. Salisbury, M. Tjernström, and P.M. Crill. 2020. Shipborne eddy covariance observations of methane fluxes constrain Arctic sea emissions. Science Advances. https://doi.org/10.1126/sciadv. aay7934.

Tian, H.Q., R.T. Xu, J.G. Canadell, R.L. Thompson, W. Winiwarter, P. Suntharalingam, E.A. Davidson, P. Ciais, et al. 2020. A comprehensive quantification of global nitrous oxide sources and sinks. Nature. https://doi.org/10.1038/s41586-020-2780-0.

Verdugo, J., E. Damm, P. Snoeijs, B. Diez, and L. Farias. 2016. Climate relevant trace gases $\left(\mathrm{N}_{2} \mathrm{O}\right.$ and $\left.\mathrm{CH}_{4}\right)$ in the Eurasian Basin (Arctic Ocean). Deep-Sea Research Part I-Oceanographic Research Papers 117: 84-94. https://doi.org/10.1016/j.dsr.2016. 08.016.

Wåhlström, I., and H.E.M. Meier. 2014. A model sensitivity study for the sea-air exchange of methane in the Laptev Sea, Arctic Ocean. Tellus b: Chemical and Physical Meteorology 66: 24174. https://doi.org/10.3402/tellusb.v66.24174.

Weber, T., N.A. Wiseman, and A. Kock. 2019. Global ocean methane emissions dominated by shallow coastal waters. Nature Communications 10: 4584. https://doi.org/10.1038/s41467-01912541-7.

Wilson, S.T., A.N. Al-Haj, A. Bourbonnais, C. Frey, R.W. Fulweiler, J.D. Kessler, H.K. Marchant, J. Milucka, et al. 2020. Ideas and 
perspectives: A strategic assessment of methane and nitrous oxide measurements in the marine environment. Biogeosciences 17: 5809-5828. https://doi.org/10.5194/bg-17-5809-2020.

Wu, L., X. Chen, W. Wei, Y. Liu, D. Wang, and B.-J. Ni. 2020. A critical review on nitrous oxide production by ammonia-oxidizing archaea. Environmental Science \& Technology 54: 9175-9190. https://doi.org/10.1021/acs.est.0c03948.

Yang, S., B.X. Chang, M.J. Warner, T.S. Weber, A.M. Bourbonnais, A.E. Santoro, A. Kock, R.E. Sonnerup, et al. 2020. Global reconstruction reduces the uncertainty of oceanic nitrous oxide emissions and reveals a vigorous seasonal cycle. Proceedings of the National Academy of Sciences 117: 11954. https://doi.org/10. 1073/pnas.1921914117.

Yvon-Durocher, G., A.P. Allen, D. Bastviken, R. Conrad, C. Gudasz, A. St-Pierre, N. Thanh-Duc, and P.A. del Giorgio. 2014. Methane fluxes show consistent temperature dependence across microbial to ecosystem scales. Nature 507: 488-491. https://doi. org/10.1038/nature13164.

Zhan, L.Y., L.Q. Chen, J.X. Zhang, J.P. Yan, Y.H. Li, and M. Wu. 2016. A permanent $\mathrm{N}_{2} \mathrm{O}$ sink in the Nordic Seas and its strength and possible variability over the past four decades. Journal of Geophysical Research-Oceans 121: 5608-5621. https://doi.org/ 10.1002/2016jc011925.

Zhan, L.Y., M. Wu, L.Q. Chen, J.X. Zhang, Y.H. Li, and J. Liu. 2017. The air-sea nitrous oxide flux along cruise tracks to the Arctic Ocean and Southern Ocean. Atmosphere 8: 216. https://doi.org/ 10.3390/atmos8110216.

Zhan, L.Y., J.X. Zhang, Z.X. Ouyang, R.B. Lei, S.Q. Xu, D. Qi, Z.Y. Gao, H. Sun, et al. 2021. High-resolution distribution pattern of surface water nitrous oxide along a cruise track from the Okhotsk Sea to the western Arctic Ocean. Limnology and Oceanography 66: S401-S410. https://doi.org/10.1002/lno. 11604.

Zhang, J., L. Zhan, L. Chen, Y. Li, and J. Chen. 2015. Coexistence of nitrous oxide undersaturation and oversaturation in the surface and subsurface of the western Arctic Ocean. Journal of Geophysical Research: Oceans 120: 8392-8401. https://doi. org/10.1002/2015JC011245.

Zhou, J., J.L. Tison, G. Carnat, N.X. Geilfus, and B. Delille. 2014. Physical controls on the storage of methane in landfast sea ice. The Cryosphere 8: 1019-1029. https://doi.org/10.5194/tc-81019-2014.

Publisher's Note Springer Nature remains neutral with regard to jurisdictional claims in published maps and institutional affiliations.

\section{AUTHOR BIOGRAPHIES}

Andrew P. Rees $(\bowtie)$ is a senior scientist at the Plymouth Marine Laboratory. His research interests include the biogeochemical cycling of carbon and nutrients and the ocean-atmosphere interaction of greenhouse gases in estuaries, coastal waters and the open ocean. Address: Plymouth Marine Laboratory, Prospect Place, The Hoe, Plymouth PL1 3DH, UK.

e-mail: apre@pml.ac.uk

Hermann W. Bange is a Professor at the GEOMAR Helmholtz Centre for Ocean Research Kiel, Germany. His research interests include trace gas biogeochemistry and the nitrogen and sulphur cycles in the open and coastal oceans.
Address: GEOMAR Helmholtz-Zentrum Für Ozeanforschung Kiel, Chemische Ozeanographie, Düsternbrooker Weg 20, 24105 Kiel, Germany.

e-mail: hbange@geomar.de

Damian L. Arévalo-Martínez is a postdoctoral researcher at the Institute of Geosciences of Kiel University and the Chemical Oceanography Department of GEOMAR Helmholtz Centre for Ocean Research Kiel. His research interests include biogeochemistry of climate-relevant trace gases, gas exchange across sea-air and sea-ice interfaces, laser spectroscopy-based methods for trace gas analysis, time-series observations, and land-ocean connectivity through groundwater.

Address: GEOMAR Helmholtz-Zentrum Für Ozeanforschung Kiel, Chemische Ozeanographie, Düsternbrooker Weg 20, 24105 Kiel, Germany.

e-mail: darevalo@geomar.de

Yuri Artioli is a senior researcher at the Plymouth Marine Laboratory. His research interests include modelling impact of climate change and ocean acidification on marine biogeochemistry and ecosystems and their feedback on climate.

Address: Plymouth Marine Laboratory, Prospect Place, The Hoe, Plymouth PL1 3DH, UK.

e-mail: yuti@pml.ac.uk

Dawn M. Ashby is a senior Communications officer at Plymouth Marine Laboratory. Her interests include science communication and generation of non-academic impact from research.

Address: Plymouth Marine Laboratory, Prospect Place, The Hoe, Plymouth PL1 3DH, UK.

e-mail: daas@pml.ac.uk

Ian Brown is a marine Chemist at the Plymouth Marine Laboratory. His research interests are the ocean-atmosphere interaction of greenhouse gases in estuaries, coastal waters and the open ocean.

Address: Plymouth Marine Laboratory, Prospect Place, The Hoe, Plymouth PL1 3DH, UK.

e-mail: ib@pml.ac.uk

Hanna I. Campen is a doctoral researcher at the Chemical Oceanography Department of GEOMAR Helmholtz Centre for Ocean Research Kiel. Her research interests include the impact of global warming on marine biogeochemistry of the climate-relevant trace gases dimethyl sulphide and carbon monoxide in the Arctic Ocean. Address: GEOMAR Helmholtz-Zentrum Für Ozeanforschung Kiel, Chemische Ozeanographie, Düsternbrooker Weg 20, 24105 Kiel, Germany.

e-mail: hcampen@geomar.de

Darren R. Clark is a senior research scientist at the Plymouth Marine Laboratory. His research interests include the biogeochemical cycling of carbon and nitrogen in marine systems.

Address: Plymouth Marine Laboratory, Prospect Place, The Hoe, Plymouth PL1 3DH, UK.

e-mail: drcl@pml.ac.uk

Vassilis Kitidis is a senior scientist at the Plymouth Marine Laboratory. His research interests in marine biogeochemistry include greenhouse gas cycling $\left(\mathrm{CO}_{2}, \mathrm{CH}_{4}, \mathrm{~N}_{2} \mathrm{O}\right)$, carbonate chemistry, dissolved organic matter and nitrogen cycling from the ocean surface to the seabed. 
Address: Plymouth Marine Laboratory, Prospect Place, The Hoe, Plymouth PL1 3DH, UK.

e-mail: vak@pml.ac.uk

Gennadi Lessin is a senior marine systems modeller at Plymouth Marine Laboratory. His research interests include development and application of modelling tools to study biogeochemical-ecological dynamics of the ocean and its response to natural and anthropogenic disturbance. His focus areas include benthic-pelagic interactions, dynamics of greenhouse gases and marine nitrogen cycle, as well as integrated analysis of ecosystem state and dynamics to inform management and policy.

Address: Plymouth Marine Laboratory, Prospect Place, The Hoe, Plymouth PL1 3DH, UK.

e-mail: gle@pml.ac.uk
Glen A. Tarran is a scientist at the Plymouth Marine Laboratory. His research interests include microbial community structure and dynamics and the role they play in the production and consumption of climatically-active gases.

Address: Plymouth Marine Laboratory, Prospect Place, The Hoe, Plymouth PL1 3DH, UK.

e-mail: gat@pml.ac.uk

Carol Turley is a senior scientist at the Plymouth Marine Laboratory. Her research interests include marine biogeochemistry and ocean policy at the international level.

Address: Plymouth Marine Laboratory, Prospect Place, The Hoe, Plymouth PL1 3DH, UK.

e-mail: ct@pml.ac.uk 